\title{
Role of magnesium sulphate in management and prevention of short term complications of birth asphyxia
}

\author{
${ }^{*}$ B Sreenivasa ${ }^{1}$, K Lokeshwari ${ }^{1}$, Nivil Joseph ${ }^{2}$ \\ Sri Lanka Journal of Child Health, 2017; 46(2): 148-151
}

\begin{abstract}
Objective: To assess the efficacy of intravenous (IV) magnesium sulphate in treating birth asphyxia and improving short term neurological outcome.
\end{abstract}

Method: A prospective study was conducted in Onake Obavva Women and Children Hospital from February 2015 to March 2016. A sample size of 100 term neonates (50 study group and 50 control group) with perinatal asphyxia were included in the study. Congenitally malformed babies and babies born to mothers who received general anaesthesia, magnesium sulphate and drugs likely to depress the baby were excluded from study. Routine protocol for asphyxiated babies in the neonatal intensive care unit (NICU) was followed in all 100 neonates. In addition, babies in the study group were given IV magnesium sulphate $250 \mathrm{mg} / \mathrm{kg} /$ dose within 6 hours of birth, after 24 hours of birth and at 48 hours of birth. During their stay in the NICU all 100 neonates were neurologically assessed.

Results: Each group comprised 50 neonates. Seizure control with a single anticonvulsant was significantly greater in the study group compared with the control group $(\mathrm{p}<0.05)$. In the study group $18.5 \%$ neonates had seizure continued at 24 hours as compared to $34.4 \%$ in the control group $(p<0.01)$. Early establishment of feeds was significantly greater in the study group compared with the control group $(\mathrm{p}<0.001)$. In study group, abnormal neurological findings were significantly less in the study group compared with the control group $(\mathrm{p}<0.01)$.

Conclusions: Postnatal IV magnesium sulphate infusion is effective in improving short term outcomes for infants with perinatal asphyxia when it is given early (within 6 hours).

${ }^{1}$ Basaveshwara Medical College Hospital and Research Centre, Chitradurga, India, ${ }^{2}$ SJM College of Pharmacy, Chitradurga, India

*Correspondence: sreenivasab@ymail.com (Received on 31 July 2016: Accepted after revision on 23 September 2016)

The authors declare that there are no conflicts of interest

Personal funding was used for the project.

Open Access Article published under the Creative

Commons Attribution CC-BY (c) (P) License.
DOI: http://dx.doi.org/10.4038/sljch.v46i2.8271

(Keywords: Perinatal asphyxia, neonates, magnesium sulphate, anticonvulsant, hypoxic ischaemic encephalopathy)

\section{Introduction}

Perinatal asphyxia is a major cause of neonatal mortality and morbidity ${ }^{1}$. About $20-30 \%$ of asphyxiated newborns who develop hypoxic ischaemic encephalopathy (HIE) die during the neonatal period, and one third to one half of survivors are left with cerebral palsy and mental retardation ${ }^{2}$. In perinatal asphyxia, glutamate, the main excitatory aminoacid neurotransmitter, is released in increased concentrations into the extracellular compartment of the brain. Two mechanisms of glutamate induced neuronal death are identified ${ }^{3}$. One is rapid cell death initiated by glutamate receptor activation. The second is initiated principally by activation of the N-methyl D-aspartate (NMDA) receptor. Magnesium is a naturally occurring NMDA receptor antagonist which is recommended for clinical use to combat glutamate toxicity and brain damage $e^{4-6}$. Literature regarding postnatal magnesium therapy after birth asphyxia revealed beneficial effects in some and no beneficial effects in others ${ }^{7-11}$.

\section{Objective}

To assess the efficacy of intravenous (IV) magnesium sulphate in treating birth asphyxia and improving short term neurological outcome

\section{Method}

The present study was conducted in Onake Obavva Women and Children Hospital attached to Basaveshwara Medical College Hospital from February 2015 to March 2016. A sample size of 100 term neonates (50 study group and 50 control group) with perinatal asphyxia were included in the study. Written, informed consent was obtained from parents and ethical approval was granted by the institutional ethics committee. Term babies admitted to the NICU who were appropriate for gestational age, with one minute Apgar score less than 3 and 5 minute Apgar score less than 6, were included in study. Congenitally malformed babies and babies born to mothers who received general anaesthesia, magnesium sulphate and drugs likely to depress the baby such as pethidine or phenobarbitone, were excluded from the study. 
Details entered in a predesigned proforma included a history of antenatal risk factors for perinatal asphyxia such as age of mother, history of pregnancy induced hypertension, anaemia, bleeding, infection and systemic disease. Intrapartum factors like mode of delivery, history of prolonged rupture of membranes, meconium stained amniotic fluid, malpresentation and cord prolapse were also entered. Examination findings, including vital functions and detailed anthropometry were recorded and a complete neurological examination was done. Routine protocol for asphyxiated babies in the neonatal intensive care unit (NICU) was followed in all 100 neonates. In addition, babies in study group were given IV magnesium sulphate $250 \mathrm{mg} / \mathrm{kg} /$ dose (1 $\mathrm{ml} / \mathrm{kg} /$ dose in $20 \mathrm{ml}$ of $5 \%$ dextrose) over 1 hour within 6 hours of birth, and this was repeated after 24 and 48 hours of birth. During the first 72 hours of life, heart rate, respiratory rate, blood pressure and oxygen saturation were continuously monitored. Assessment of the neurologic status, including sensorium, tone, primitive postural reflexes, grade of HIE (Sarnat stages 1-3), presence of seizures, time to establish full oral feedings through sucking, were done for all 100 newborns. Baseline serum magnesium was measured soon after delivery, at 24 and 48 hours in both groups. Serum magnesium was measured using magnesium kit provided by CREST biosystems using Calmagite method. Descriptive statistics, Chi square/contingency coefficient analysis, independent samples $t$ test) were carried out through the SPSS for windows (version 16.0). A p value $<0.05$ was taken as statistically significant.

\section{Results}

A total of 100 term, appropriate for gestational age babies with birth asphyxia were studied, 50 babies each in study and control groups. In the study group 32 were males and 18 were females, whereas in the control group 30 were males and 20 were females. HIE staging was comparable between the two groups. The study group had 18 stage 1,28 Stage 2 and 4 Stage 3 HIE whilst the control group had 21 stage 1, 26 stage 2 and 3 stage 3 HIE. Mean birth weight, gestational age, Apgar score at 1 and 5 minutes, mean serum magnesium levels and were also comparable between the two groups (Table 1).

Table 1; Baseline characteristics of the study group and control group

\begin{tabular}{|l|c|c|c|}
\hline \multicolumn{1}{|c|}{ Characteristic } & $\begin{array}{c}\text { Study group (n=50) } \\
\text { Mean } \pm \text { SD }\end{array}$ & $\begin{array}{c}\text { Control group (n=50) } \\
\text { Mean } \pm \text { SD }\end{array}$ & P value \\
\hline Birth weight (kg) & $2.76 \pm 0.24$ & $2.79 \pm 0.29$ & $>0.05$ \\
\hline Gestational age (weeks) & $38.8 \pm 0.5$ & $38.6 \pm 0.4$ & $>0.05$ \\
\hline Apgar score at 1 minute & $1.64 \pm 0.57$ & $1.74 \pm 0.43$ & $>0.05$ \\
\hline Apgar score at 5 minutes & $4.7 \pm 1.18$ & $4.85 \pm 1.08$ & $>0.05$ \\
\hline Mean serum magnesium level (meq / L) & $1.63 \pm 0.40$ & $1.65 \pm 0.53$ & $>0.05$ \\
\hline
\end{tabular}

The heart rate, oxygen saturation and respiratory rate showed no significant fall after magnesium administration. No adverse effects of magnesium were noted in this study. The results of the present study revealed that magnesium sulphate in birth asphyxia helps in better seizure control, early initiation of feeding and better neurological outcome (Table 2).

Table 2: Results of the study groups

\begin{tabular}{|c|c|c|c|}
\hline Characteristic & $\begin{array}{l}\text { Study group } \\
\quad(n=50)\end{array}$ & $\begin{array}{c}\text { Control group } \\
(n=50)\end{array}$ & P value \\
\hline Mortality- No. (\%) & $03(06)$ & $04(08)$ & $\mathrm{P}>0.05$ \\
\hline Seizures present- No. (\%) & $27(54.0)$ & $29(58.0)$ & $\mathrm{P}>0.05$ \\
\hline Seizures controlled with 1 anticonvulsant- No. (\%) & $26(96.2)$ & $21(72.4)$ & $\mathrm{P}<0.05$ \\
\hline Seizures continued at 24 hours- No. (\%) & $05(18.5)$ & $10(34.4)$ & $\mathrm{P}<0.01$ \\
\hline $\begin{array}{l}\text { Mean duration of recovery from neurological abnormality } \\
\text { in days- }(\mathrm{Mean} \pm \mathrm{SD})\end{array}$ & $3.56 \pm 1.23$ & $5.01 \pm 1.62$ & $\mathrm{P}<0.001$ \\
\hline Mean duration in days for initiation of feeding & & & \\
\hline Nasogastric tube feeding- (Mean $\pm \mathrm{SD})$ & $3.25 \pm 1.12$ & $4.02 \pm 1.03$ & $\mathrm{P}<0.001$ \\
\hline Spoon feeding- $($ Mean \pm SD $)$ & $3.90 \pm 1.26$ & $5.80 \pm 1.41$ & $\mathrm{P}<0.001$ \\
\hline Direct breast feeding- (Mean $\pm \mathrm{SD})$ & $4.90 \pm 1.56$ & $6.30 \pm 1.67$ & $\mathrm{P}<0.001$ \\
\hline $\begin{array}{l}\text { Neurological findings at discharge } \\
\text { Abnormal neurological findings at discharge- No. (\%) }\end{array}$ & $12(25.5)$ & $22(47.8)$ & $\mathrm{P}<0.01$ \\
\hline Normal neuromotor tone (Amiel Tison criteria) - No. (\%) & $35(74.4)$ & $19(41.3)$ & $\mathrm{P}>0.05$ \\
\hline Normal neuroimaging - No. $(\%)$ & $34(72.3)$ & $19(41.3)$ & $\mathrm{P}<0.05$ \\
\hline Mean serum magnesium levels (meq / L) & & & \\
\hline After 24 hours $-($ Mean \pm SD $)$ & $2.71 \pm 0.61$ & $1.66 \pm 0.54$ & $\mathrm{P}<0.001$ \\
\hline After 72 hours $-($ Mean \pm SD) & $2.81 \pm 0.71$ & $1.69 \pm 0.61$ & $\mathrm{P}<0.001$ \\
\hline
\end{tabular}




\section{Discussion}

Many studies have confirmed the neuroprotective role of magnesium sulphate both in animals and human beings, but still there is apprehension regarding the adverse outcome of magnesium sulphate on vital parameters of babies. Our study was carried out to re-establish the safety of magnesium sulphate infusion and to study the immediate neurological outcome in such babies.

Based on the pharmacokinetics and estimates of plasma half-life of magnesium sulphate as reported by Levene et $a l^{12}$, the dosage used in present study will ensure plasma concentration of magnesium in the neuroprotective range at 72 hours. The neuroprotective range of serum magnesium is $2.4-5$ $\mathrm{meq} / \mathrm{L}^{12}$. We recommend the dosage schedule of magnesium infusion used by us for further trials as the same has been documented to achieve serum magnesium levels in the neuroprotective range and is safe.

The favourable outcome related to seizure control might be due to following properties of magnesium - its central anticonvulsant effect on hippocampal seizures, cerebral vasodilatory properties, reduction of calcium influx by gating NMDA receptor in brain, antagonizing glutamate excitotoxicity ${ }^{4,5}$. However, in contrast to our study, Ichiba $\mathrm{H}$ et al, found no significant difference in the clinical seizures between 2 groups ${ }^{7}$. This conflicting result could be because they had a smaller sample size. In the present study significantly less number of neonates had neurological abnormalities at discharge in study group. Similar results were obtained in other studies ${ }^{7,8}$. These findings confirm that magnesium has definite neuroprotection in asphyxiated neonates.

The overall mortality in the present study was $14 \%$. Most deaths occurred in the initial neonatal period because of asphyxia and its complications. However, the mortality was similar in the study and control groups. Secondary injury to the posthypoxic neonatal brain can occur over a period that may last as long as 72 hours $^{13}$. If the magnesium ion was to be evaluated as a neuroprotective agent in severely asphyxiated infants a dosing regimen aimed at maintaining increased concentrations for 72 hours would be necessary. Based on the estimates of a plasma half-life of magnesium sulphate reported here, an effective dosing regimen comprises $250 \mathrm{mg} / \mathrm{kg}$, followed by two further infusions at 24 hours and 48 hours. This would ensure that plasma concentrations of the magnesium ion was maintained in the range $2.4-5$ meq / L.

One limitation in the present study was not using umbilical cord $\mathrm{pH}$ and base deficit to either diagnose or quantitate the severity of asphyxia. Not doing special investigations such as diffusion weighted imaging (DWI), magnetic resonance spectroscopy (MRS) and amplitude integrated electroencephalography and lack of long term follow up to assess future neurologic sequelae are other limitations.

\section{Conclusions}

Postnatal IV magnesium sulphate infusion is effective in improving short term outcomes for infants with perinatal asphyxia when it is given early (within 6 hours).

\section{References}

1. Gathwala G, Khera A, Singh J, Balhara B. Magnesium for neuroprotection in birth asphyxia. Journal of Pediatric Neurosciences 2010; 5:102-4. https://doi.org/10.4103/1817-1745.76094 PMid: 21559152 PMCid: PMC3087983

2. Namasivayam A, Waldemar AC. Hypoxic Ischaemic Encephalopathy. In: Behrman RE, Kliegman RM, Jenson HB editors. Nelson Textbook of Pediatrics. First south Asia edition. Philadelphia: Saunders Publishers, 2015:569-570.

3. Barks JDE, Silverstein FS. Excitatory amino acids contribute to the pathogenesis of perinatal hypoxic ischemic brain injury. Brain Pathology 1992; 2: 235-43. https://doi.org/10.1111/j.1750-

3639.1992.tb00697.x

4. Gathwala G. Neuronal protection with magnesium. Indian Journal of Pediatrics 2001; 68:4179.

https://doi.org/10.1007/BF02723017

5. Chahal H, D'Souza S, Barson A, Slater P. Modulation by magnesium of N-methyl-D aspartate receptors in developing human brain. Archives of Disease in Childhood Fetal and Neonatal Edition 1998; 78:11620.

https://doi.org/10.1136/fn.78.2.F116

6. Szemraja J, Sobolewskab B, Gulczynska E, Wilczynski J, Zylinska L. Magnesium sulfate effect on erythrocyte membranes of asphyxiated newborns. Clinical Biochemistry 2005; 38:457- 64. https://doi.org/10.1016/j.clinbiochem.2005 .02 .005

PMid: 15820777 
7. Ichiba H, Tamai H, Negishi H, Ueda T, Kim TJ, Sumida Y et al. Randomized controlled trial of magnesium sulfate infusion for severe birth asphyxia. Pediatrics International 2002; 44:505-9. https://doi.org/10.1046/j.1442200X.2002.0 1610.x

PMid: 12225549

8. Ichiba H, Yokoi T, Tamai H, Ueda T, Kim TJ, Yamano T. Neurodevelopmental outcome of infants with birth asphyxia treated with magnesium sulfate. Pediatrics International 2006; 48:705.

https://doi.org/10.1111/j.1442200X.2006.0

2167.x

PMid: 16490075

9. Bhat MA, Charoo BA, Bhat JI, Ahmad SM, Ali SW, Mufti MUH. Magnesium sulfate in severe perinatal asphyxia: A randomized placebo- controlled trial. Pediatrics 2009; 123:764-9.

https://doi.org/10.1542/peds.2007-3642

PMid: 19349375

10. McGuire W. Perinatal Asphyxia. BMJ Clinical Evidence 2007; 2007: 0320.

11. Groenendaal F, Rademaker CM, Toet MC, de Vries LS. Effects of magnesium sulphate on amplitude integrated continuous EEG in asphyxiated term neonates. Acta Paediatrica 2002; 91:10737.

https://doi.org/10.1111/j.16512227.2002.t b00102.x

PMid: 12434893

12. Levene $M$, Blennow $M$, Whitelaw $A$, Hanko E, Fellman V, Hartley R. Acute effects of two different doses of magnesium sulphate in infants with birth asphyxia. Archives of Disease in Childhood Fetal and Neonatal Edition 1995; 73:174-7.

https://doi.org/10.1136/fn.73.3.F174

13. Roth SC, Edwards AD, Cady EB, Delpy DT, Wyatt JS, Azzopardi D, et al. Relation between cerebral oxidative metabolism following birth asphyxia and neurodevelopmental outcome and brain growth at one year. Developmental Medicine and Child Neurology 1992; 34:285-95.

https://doi.org/10.1111/j.14698749.1992.t b11432.x

PMid: 1572514 